\title{
Microplastic Characterization in Soil Samples in Urban and Rural Areas of Eskişehir
}

\author{
Esin Huriye Buğdayci ${ }^{1 *}$, Burcu Şimşek Uygun ${ }^{2}$

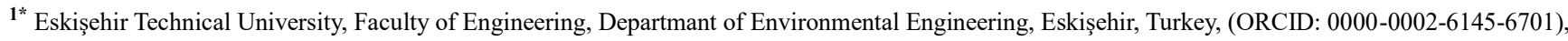 \\ bugdayciesin@gmail.com \\ ${ }^{2}$ Eskişehir Technical University, Faculty of Engineering, Departmant of Environmental Engineering, Eskişehir, Turkey, (ORCID: 0000-0003-1211-4198), \\ bsimsek1@eskisehir.edu.tr
}

(1st International Conference on Applied Engineering and Natural Sciences ICAENS 2021, November 1-3, 2021)

(DOI: 10.31590/ejosat.1012889)

ATIF/REFERENCE: Buğdayc1, E. H. \& Şimşek Uygun, B. (2021). Microplastic Characterization in Soil Samples in Urban and Rural Areas of Eskişehir. European Journal of Science and Technology, (28), 1419-1423.

\begin{abstract}
Plastics, which are widely used in daily life, are preferred in many areas from the construction sector to the textile sector due to some of their features such as ease of processing and being economical. Nearly 9 million tons of plastic have been produced so far, most of which is emitted as pollution. These plastics, which turn into particles smaller than $5 \mathrm{~mm}$ called "microplastic" by exposure to some physical effects such as sunlight, wind and waves, increase pollution due to their smaller size and densities and spread to much wider areas. Microplastics, which can be formed by the disintegration of large-sized plastics, threaten the living and non-living environment with their non-degradable structures. The severity of microplastic pollution, which can be defined as invisible pollution, should be better understood and awareness should be raised about the impact of its negative consequences. The aim of this study is to reveal the microplastic pollution in soil environments of rural and urban areas in Eskişehir. In the study, soil samples taken from urban and rural areas were visually analyzed. As a result, it was observed that the microplastic density was higher in urban samples. In addition, by visual analysis of microplastics, it was determined that the most common type was fiber type, and black colored microplastics were seen most frequently.
\end{abstract}

Keywords: Microplastic, microplastic in soil, microplastic accumulation, soil pollution.

\section{Eskişehir'in Kentsel ve Kırsal Bölgelerindeki Toprak Örneklerinde Mikroplastik Karakterizasyonu}

$\ddot{O ̈ z}$

Günlük hayatta yaygın olarak kullanılan plastikler, işlenme kolaylığı ve ekonomik olması gibi bazı özelliklerinden dolayı inşaat sektöründen tekstil sektörüne kadar birçok alanda tercih edilmektedir. Şimdiye kadar, çoğu kirlilik olarak yayılan yaklaşık 9 milyon ton plastik üretilmiştir. Güneş 1şı̆̆ı, rüzgar, dalga gibi bazı fiziksel etkilere maruz kalarak "mikroplastik" adı verilen 5 mm'den küçük parçacıklara dönüşen bu plastikler, daha küçük boyutları ve yoğunlukları nedeniyle kirliliği artırmakta ve çok daha geniş alanlara yayılmaktadır. Büyük boyutlu plastiklerin parçalanmasıyla oluşabilen mikroplastikler, parçalanmayan yapılarıyla canlı ve cansız çevreyi tehdit etmektedir. Görünmez kirlilik olarak tanımlanabilecek mikroplastik kirliliğinin ciddiyeti daha iyi anlaşılmalı ve olumsuz sonuçlarının etkisi konusunda farkındalık oluşturulmalıdır. Bu çalışmanın amacı Eskişehir'de kırsal ve kentsel alanların toprak ortamlarındaki mikroplastik kirliliğini ortaya çıkarmaktır. Çalışmada kentsel ve kırsal alanlardan alınan toprak örnekleri görsel olarak analiz edilmiştir. Sonuç olarak kentsel örneklerde mikroplastik yoğunluğunun daha yüksek olduğu gözlemlenmiştir. Ayrıca mikroplastiklerin görsel analizi ile en yaygın türün fiber türü olduğu, siyah renkli mikroplastiklerin ise en sık görüldüğü belirlenmiştir.

Anahtar Kelimeler: Mikroplastik, toprakta mikroplastik, mikroplastik birikimi, toprak kirliliği.

* Corresponding Author: bugdayciesin@gmail.com 


\section{Introduction}

Plastics, which are synthetic polymers, are one of the most important environmental pollutants today. Plastics are highly preferred because they are flexible, workable, economical, insulating (electrical and heat insulation) and light, and they have many usage areas. Kitchenware, toys, packaging, textiles are mostly plastic products.

It is seen that plastic production and plastic pollution have increased gradually. Today, although the production is about 350 million tons, only $10 \%$ of this value is recycled. For this reason, the accumulation of plastic waste also increases and many water and soil environments become contaminated. It is thought that there are 100-150 million tons of plastic in the seas and oceans.

Plastic particles smaller than $5 \mathrm{~mm}$, which are formed as a result of decomposition by exposure to sunlight, waves or various physical effects, are called microplastics and can be examined in 2 different categories. Microplastics formed as a result of direct use (such as microbeads widely used in cosmetic materials) are called primary microplastics, and microplastics formed by the breakdown of larger plastics are called secondary microplastics (Yurtsever, M., 2015). In this regard, Fendall (2009) discovered in a study conducted for the aquatic environment that facial cleansers are an important source of microplastic pollution for the seas (Ceylan,B., 2017).

It is possible to say that the foundations of microplastics were laid within the scope of the study carried out by Gregory on the New Zealand coasts in 1977 (Aydın,E., 2020). Thompson (2004), on the other hand, used the word microplastic for the first time in his studies on plastic pollution in aquatic environments (Gürbüz,Ö., 2017).

Due to their small size and low density, microplastic particles diffuse faster into the environment than large plastic particles. Microplastics spread easily in this way, polluting many environments. Free (2014) encountered microplastics even in the Hovsgol mountain lake, which is far from the residential area (Aydin, 2020). In addition, 38-234 particles per $\mathrm{m} 3$ of ice were reported in the Arctic in a study by Obbard et al. (Guo,J.J, 2020).

Microplastics, which enter the bodies of living things in different environments, accumulate in the human body through the food chain. Roex et al. (2013), in a study they conducted in the Netherlands, determined that microplastics are taken into their body by both animals and humans, and they said that they have negative effects on health (Sema, B.Z., 2020).

Meral Y.(2017), as a result of her investigations on 10 different brands of sea, lake and rock salts purchased from some markets in Sakarya/Turkey, found that microplastics amounted to approximately $28 \mathrm{MP} / 200 \mathrm{~g}$ in rock salts, around 56 in sea salts, and $63 \mathrm{MP} / 200 \mathrm{~g}$ in lake salts (Yurtsever, M., 2018).

Due to agricultural activities, discharge of waste garbage, sewage sludge and plastic factory waste to the soil, microplastics are abundant in the soil and this is very important. Pim Van Den Berg et al. sampled a wastewater treatment plant and farmland in eastern Spain and showed that treatment of sewage sludge causes accumulation of microplastics in agricultural soils (Berg, P. et al.,2020). One of the biggest negative effects of microplastics on soil is that it causes changes in soil structure. It is known that as a result of microplastic contamination, there is a decrease in the water holding capacity of the soil and the microbiological e-ISSN: 2148-2683 activities in the (MacHado,A.A., et al., 2018). Microplastic pollution causes degradation of soil biota. Microplastics, which are absorbed by the roots of plants living in the soil, damage plant vitality (Li, L. et al.,2020). In addition, microplastics can adsorb pollutants such as persistence organic compounds and heavy metals and damage the soil structure by increasing the concentration of these pollutants in the soil. In a study conducted in China, it was determined that heavy metals such as $\mathrm{Cd}, \mathrm{Pb}, \mathrm{Hg}$ contents on microplastic particles were strongly related to the these contents in the soil (Zou, X., et al., 2020). Although microplastics are so widespread and polluting in the soil environment, the scarcity of research on this subject is known and the number of studies on microplastics in terrestrial ecosystems should increase.

\section{Material and Method}

\subsection{Study Area}

For this research, soil samples were taken from different regions of Eskişehir, two rural and two urban points. Microplastic pollution was analyzed in the samples taken from Yenibağlar District and Kanlıkavak Park in the city center as an urban area, and the samples taken from Borabey Pond located in the north of the city center and Musaözü Pond in the south of the city center are as a rural area. While choosing the rural area, it was an important factor that the selected areas were far from the residential area and urban activities. However, there is a possibility that pollutants may reach the area as a result of natural events such as wind, rain and snow. Therefore, the wind direction is a factor taken into account during the research.

In this study, the aim of taking soil samples from urban and rural areas and examining them is to consider microplastic pollution and to make a rural-urban comparison at the same time. The locations of the sampled stations on the map of Eskişehir are shown in Figure 1.

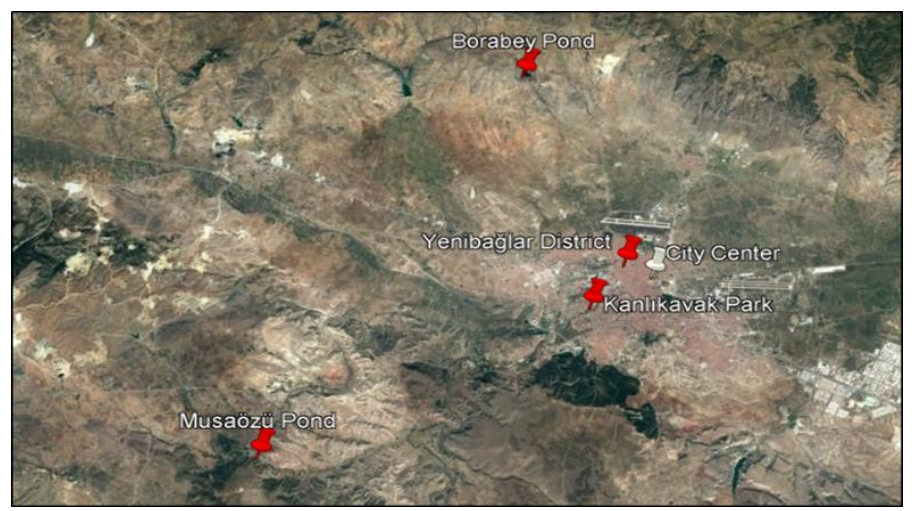

Figure 1. Sampling Points

Soil, composed of materials such as organic matter, minerals and chemicals, is a highly heterogeneous system. Microplastics can be embedded in this system and it can be difficult to separate from the soil. To characterize microplastics in soils, rapid, highefficiency, easy and reliable analytical techniques are required.

There is no definitive accepted method for the identification of microplastics in soil. But it can be said that it consists of the following 3 phases; extraction, removal of organic material from soil and identification. 


\subsection{Extraction of Soil Samples}

After the location and number of sampling points are determined, the soil sample is taken appropriately, after this process, the sample is dried and sieved. The sieving process is the first step of the analysis and the sieve pore sizes used are important. There are different sieve sizes and different sieve uses recommended for soil samples with different properties. After the sieving process has been carried out, it is necessary to separate the microplastics from the soil environment. Since the densities of microplastics (0.8-1.4 g/cm3) are lower than the soil density (2.6$2.7 \mathrm{~g} / \mathrm{cm} 3)$, microplastic particles can be removed from the soil by using different density solutions such as $\mathrm{NaCl}$ (sodium chloride), $\mathrm{CaCl}_{2}$ (calcium chloride), $\mathrm{ZnCl}_{2}$ and $\mathrm{NaI}$ (sodium iodide). In most of the studies, saturated sodium chloride $(\mathrm{NaCl})$ is used as salt solution for density separation (He,D., et al.,2018). Thompson et al. (2004), Reddy et al. (2006), Browne et al. (2010), Claessens et al. (2011) have made several attempts to monitor microplastics in sediments based on density separation in sodium chloride $(\mathrm{NaCl})$ solutions (Nuelle, M., et al., 2014).

Concentrated $\mathrm{ZnCl}_{2}$ has the appropriate density $\left(1.55 \mathrm{~g} / \mathrm{cm}^{3}\right)$, but its solution is corrosive and toxic. Although the solution density of $\mathrm{NaI}$ is quite high $\left(1.8 \mathrm{~g} / \mathrm{cm}^{3}\right)$ is a great advantage, $\mathrm{NaI}$ is expensive. $\mathrm{CaCl}_{2}$ solution is a suitable substance for separating microplastics from soil. However, $\mathrm{Ca}^{+2}$ ions can promote the extraction of organic material. All commonly used density solutions have some limitations. Although there may be points where the maximum solution density of $\mathrm{NaCl}$ remains low, it is frequently used because it is easy to obtain and useful.

In this study, the soil samples taken were laid on separate blotting papers in the laboratory environment and kept at room temperature for one day. Then, the dried samples were sieved by placing sieves of $4 \mathrm{~mm}, 2.8 \mathrm{~mm}, 2 \mathrm{~mm}, 1.4 \mathrm{~mm}, 1 \mathrm{~mm}, 710 \mu \mathrm{m}$, $500 \mu \mathrm{m}, 250 \mu \mathrm{m}$ and $125 \mu \mathrm{m}$ from top to bottom, respectively. Thus, all parts between $4 \mathrm{~mm}$ and $250 \mu \mathrm{m}$ in size were taken.

It is mixed with the prepared saturated $\mathrm{NaCl}$ solution and soil samples. Thus, the density difference was clarified and the part containing microplastic was exposed to the surface. By collecting and removing these microplastics on the surface, most of the sludge and organic matter is removed.

\subsection{Organic Material Removal}

Since the densities of organic materials in the soil are low (1.0-1.4 g/cm3), a single density separation method is not sufficient to separate microplastics from the soil environment. For this purpose, the cleaning procedure is the most commonly used method to remove organics from the soil. Various methods have different efficiencies. In the tests performed, it was determined that the removal with $\mathrm{HNO}_{3}$ took place in a short time. However, this process caused some plastics to decompose into smaller debris. Liebezeit and Dubaish (2012) suggested pre-treatment of sediments using a $30 \% \mathrm{H}_{2} \mathrm{O}_{2}$ solution to remove natural organic residues (Nuelle, Dekiff, Remy, \& Fries, 2014). In addition, in the study of Hurley et al., the yields of $30 \% \mathrm{H}_{2} \mathrm{O}_{2}$, Fenton reagent, $\mathrm{NaOH}$ solution, $10 \%$ potassium hydroxide $(\mathrm{KOH})$ solutions were compared, and temperature as $40^{\circ} \mathrm{C}$ were used. In the soil sample, the removal of organic material with the highest efficiency was achieved with $\mathrm{H}_{2} \mathrm{O}_{2}$ (Hurley,R.R., et al.,2018).

Within the scope of this study, $\mathrm{H}_{2} \mathrm{O}_{2}$ and $40{ }^{\circ} \mathrm{C}$ temperature were used chemically. With the addition of $\mathrm{H}_{2} \mathrm{O}_{2}$, the final solution was left in the magnetic stirrer for 1 day and kept for organic matter removal. After the solution was taken from the mixer, the same process was applied once more in order to increase the yield.

\subsection{Physical Characterization}

It is difficult to precisely and reliably identify microplastics of various sizes, shapes and polymer types from the complex soil using a single analytical method. Therefore, the combination of more than one analytical technique is widely used.

Analysis of microplastics can be divided into two parts as physical and chemical analysis. For physical analysis, the sample is examined under a microscope and the purpose is to identify the microplastic. In this visual analysis, they can be classified according to their features such as size, shape and color ( Crawford, C.B., and Quinn,B., 2016), (Prata, J.C., et al., 2019). Scanning electron microscopy (SEM) can provide extremely clear, high-magnification images of plastic-like particles. Polarized optical microscopy has been successfully used to identify polyethylene (PE) particles in toxicity experiments (Shim, W., et al., 2017).

For chemical analysis, spectroscopic and thermal analysis methods are used (Li,L. et al., 2020). Fourier transform infrared (FTIR) spectroscopy provides information about the chemical structure of particles. Raman Spectroscopy can analyze microplastics from 1-20 $\mu$ meters in size. However, it is an expensive device and requires a large amount of time (Shim, W., et al., 2017)., (Kumar,M., et al, 2020). Differential scanning calorimetry (DSC) is a useful method to study the thermal properties of polymeric materials and can be useful in identifying specific primary microplastics (Shim, W., et al., 2017).

In this study, light microscopy was used while examining microplastics. All of the microscope images used within the scope of this project were first examined with $4 \mathrm{x}$, and then final views were obtained with the 10x zoom option.

\section{Results and Discussion}

The lack of a standard method for the proper separation of microplastics from soil environments is a major shortcoming. Microplastics in soil can be in micro dimensions, making identification even more difficult. In addition, microplastic pollution seriously affects living life negatively. Microplastics can adsorb toxic substances, move freely in the environment, and pose great dangers to the ecosystem by surviving for many years.

A large amount of microplastic particles were found in the soil sample taken from the Kanlıkavak Park route around the city center. These; particle and fiber type. Fiber microplastics were observed in red, blue and black colors, and particle microplastics were observed in green and purple colors. The sample taken from Yenibağlar District route was examined with a microscope and microplastics of different colors such as black, green and red fiber type were found. Apart from this, particles were also detected in the film type.

When the sample taken from the Borabey Pond route in the rural area was examined, no microplastics of any other type than fiber were found. Most of these fiber-type microplastic particles were black in color, with one seen in blue. In the sample taken from the Musaözü Pond route, microplastic particles of black colored fiber and particle type were found. 
As a result, it can be said that more microplastics were found in urban soil samples compared to rural areas. After the literature review, it was expected that microplastic pollution would be higher in the city center and areas close to the center. As a result of the examinations and laboratory researches, it was seen that this expectation came true. Regarding the reason for this, the population density in the city center and also the abundance of activities that may cause plastic pollution can be shown. Another conclusion that can be drawn from the results of the research is that different types of microplastics can be seen in these areas, regardless of whether they are far or close to residential areas. This shows how easily microplastics can spread over large areas. In addition, it is estimated that microplastic pollution in this area does not increase or decrease due to the wind effect.

The images obtained under the microscope of the microplastics found on the routes in the research are given below.

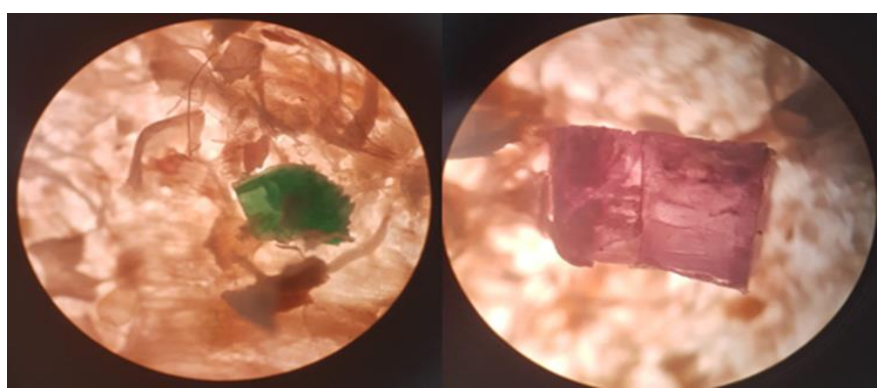

Figure 2. Particle Type Microplastic Images in Samples from the Kanlıkavak Park

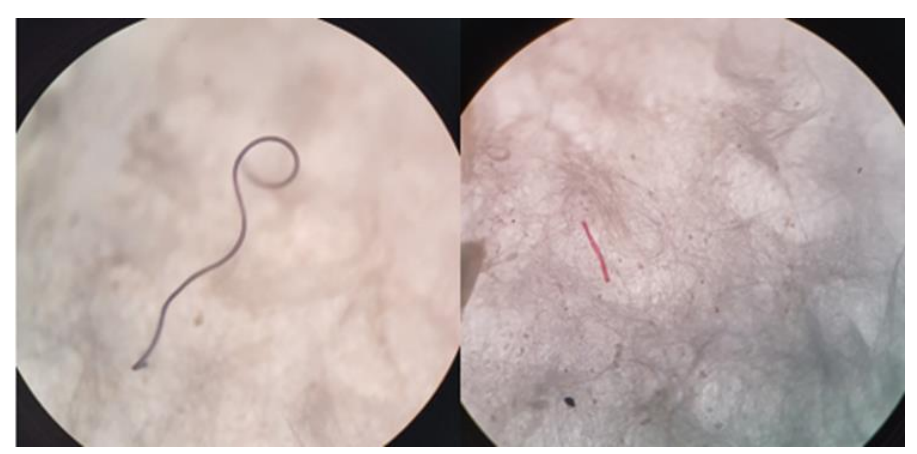

Figure 3. Fiber Type Microplastic Images in Samples from Yenibağlar District

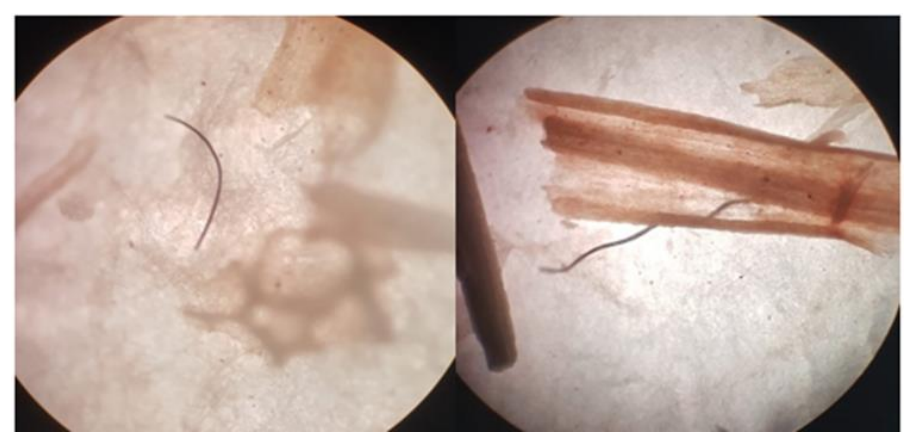

Figure 4. Fiber Type Microplastic Images in Samples from Musaözü Pond

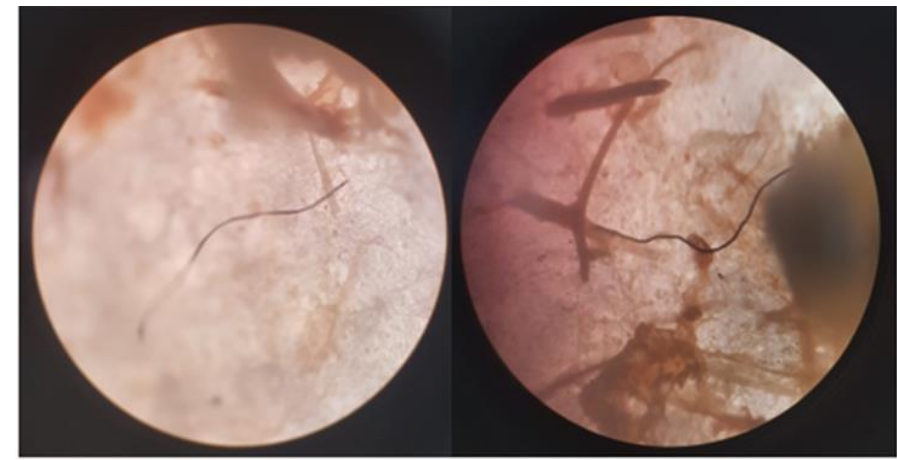

Figure 5. Fiber Type Microplastic Images in Soil Samples from Borabey Pond

\section{Conclusions and Recommendations}

Plastics are widely used, and the damage of small plastic particles, which we call microplastics, to the natural environment and human life, and their rate of diffusion into the environment are known. When the literature and the result of this study are examined, serious dimensions of microplastic pollution are seen. For this reason, awareness on microplastic pollution should increase day by day and research on this issue should be increased.

\section{Acknowledgement}

The authors are thankful to Mine Sağdıç Ulusoy for helping extraction part during the studies.

\section{References}

A. A. De Souza MacHado et al., "Impacts Of Microplastics On The Soil Biophysical Environment," Environ. Sci. Technol., 2018.

Aydın, E. (2020, Mayıs). Yüzey Sularında Mikroplastik Kirliliğinin İncelenmesi. Yüksek Lisans Tezi, ERÜ Fen Bilimleri Enstitüsü.

Berg, P., Huerta-Lwanga, E., Corradini, F., \& Geissen, V. (2020). Sewage Sludge Application As A Vehicle For Microplastics In Eastern Spanish Agricultural Soils. Environmental Pollution 261, 114198.

C. B. Crawford and B. Quinn, Microplastic Pollutants. 2016.

Ceylan, B. (2017, Mart). Atıksulardaki Mikroplastik Kirliliğinin İncelenmesi. Yüksek Lisans Tezi, S.Ü. Fen Bilimleri Enstitüsü.

D. He, Y. Luo, S. Lu, M. Liu, Y. Song, and L. Lei, "Microplastics In Soils: Analytical Methods, Pollution Characteristics And Ecological Risks," TrAC - Trends Anal. Chem., vol. 109, pp. 163-172, 2018.

Guo, J.J. (2020). Source, Migration And Toxicology Of Microplastics In Soil. Environment International 137.

Gürbüz, Ö. (2017, Aralık). Marmara Denizi Mikroplastik Karakterizasyonu ve Dağılımı. Yüksek Lisans Tezi, İ.Ü. Deniz Bilimleri ve İşletmeciliği Enstitüsü.

J. C. Prata, J. P. da Costa, A. C. Duarte, and T. Rocha-Santos, "Methods For Sampling And Detection Of Microplastics In Water And Sediment: A Critical Review," TrAC - Trends in Analytical Chemistry. 2019.

L. Li et al., "Effective Uptake Of Submicrometre Plastics By Crop Plants Via A Crack-entry Mode," Nat. Sustain., 2020. 
M. Kumar et al., "Microplastics As Pollutants In Agricultural Soils," Environmental Pollution. 2020

Nuelle, M., Dekiff, J., Remy, D., \& Fries, E. (2014). A New Analytical Approach For Monitoring Microplastics In Marine Sediments. Environmental Pollution, 184, 161-169.

Sema, B. Z. (2020, Ağustos). Bazı Gidalardaki Mikroplastik Kirliliğinin Tespiti. Yüksek Lisans Tezi, S.Ü. Fen Bilimleri Enstitüsü.

R. R. Hurley, A. L. Lusher, M. Olsen, and L. Nizzetto, "Validation of a Method for Extracting Microplastics from Complex, Organic-Rich, Environmental Matrices," Environ. Sci. Technol., 2018

Shim, W., Hong, S., \& Eo, S. (2017). Identification Methods In Microplastic Analysis: A Review. Critical Review.

Yurtsever, M. (2015). Mikroplastiklere Genel Bir Bakış. Dokuz Eylül Üniversitesi Mühendislik Fakültesi Fen ve Mühendislik Dergisi.

Yurtsever, M. (2018). Abiyotik Bir Su Ürünü Olan Sofra Tuzunda Mikroplastik Kirliliği Tehlikesi. Su Ürünleri Dergisi.

Zhang, B., Yang, X., Liang, C., Jinyu, C., Jia, T., \& Qing, W. (2019). Microplastics In Soils: A Review of Possible Sources, Analytical Methods and Ecological Impacts. Society of Chemical Industry.

Zhou, X. Liu, and J. Wang, "Characterization Of Microplastics And the Association Of Heavy Metals With Microplastics In Suburban Soil Of Central China," Sci. Total Environ., 2019. 